\title{
The Creative Neurons
}

\author{
Mark V. Flinn* \\ Department of Anthropology, Baylor University, Waco, TX, United States
}

Creativity generates novel solutions to tasks by processing information. Imagination and mental representations are part of the creative process; we can mull over ideas of our own making, and construct algorithms or scenarios from them. Social scenariobuilding can be viewed as a human cognitive "super-power" that involves abstraction, meta-representation, time-travel, and directed imaginative thought. We humans have a "theater in our minds" to play out a near-infinite array of social strategies and contingencies. Here we propose an integrative model for why and how humans evolved extraordinary creative abilities. We posit that a key aspect of hominin evolution involved relatively open and fluid social relationships among communities, enabled by a unique extended family structure similar to that of contemporary hunter-gatherer band societies. Intercommunity relationships facilitated the rapid flow of information- "Culture"-that underpinned arms-races in information processing, language, imagination, and creativity that distinguishes humans from other species.

\section{OPEN ACCESS}

Edited by:

Rex Eugene Jung,

University of New Mexico,

United States

Reviewed by:

Geoff Kushnick,

Australian National University,

Australia

Michael Charles Corballis,

The University of Auckland,

New Zealand

*Correspondence:

Mark V. Flinn

mark_flinn@baylor.edu

Specialty section

This article was submitted to

Theoretical and Philosophical

Psychology,

a section of the journal

Frontiers in Psychology

Received: 27 August 2021

Accepted: 15 October 2021

Published: 22 November 2021

Citation:

Flinn MV (2021) The Creative

Neurons. Front. Psychol. 12:765926.

doi: 10.3389/fpsyg.2021.765926
Keywords: creativity, innovation, evolution, family, culture

\section{INTRODUCTION: ORIGINS}

Novelty is risky because the outcomes of untried behaviors may be difficult to predict. Unbridled changes, like mutations, usually have deleterious results as they stray from proven recipes. Hence organisms have evolved constraints on innovation (Lefebvre et al., 2004; Brosnan and Hopper, 2014), and learned transmission biases (Campbell, 1960; Shettleworth, 1998). Our hominin ancestors, however, did something extraordinary: they evolved cognitive aptitudes that underpin a system of cumulative culture that generates rates of innovation that are orders of magnitude faster and more efficient than other species (Tomasello, 1999, 2016; Whiten and Erdal, 2012; Legare and Nielsen, 2015; Fuentes, 2017; Wadley, 2021; cf. Bandini and Harrison, 2020). The puzzle is, why humans? Why not chimpanzees or bonobos or elephants or dolphins or ants? Why are humans alone the "hyper-cultural" species? What were the selective pressures that among all God's creatures pushed our hominin ancestors so rapidly and extensively down the evolutionary pathway of innovative and cumulative culture?

Humans (H. sapiens) have big $(\sim 1,300 \mathrm{cc})$ brains, walk upright, use projectile weapons, do not have outward cues of ovulation, have menopause, and an extended period of child development. This suite of characteristics distinguishes us from our primate relatives and may provide important insights into hominin evolution (Alexander, 1990b; Chapais, 2008; Milks et al., 2019). An additional critical human trait is the expanded family. Hominins increasingly diverged from our hominoid relatives in paternal, sibling, grandparental, mating, and affinal relationships (Hrdy, 1981, 2009; Chapais, 2008; Hawkes, 2020), although the timing is uncertain (Duda and Zrzavý, 2013). Human brothers and sisters maintain life-long connections across residential distance. Affines (e.g., "inlaws") and other non- or distant kin cooperate in complex ways (e.g., Macfarlan et al., 2014; Chagnon et al., 2017). Grandparents link multiple generations. These relationships facilitate 
the flexible "nested-coalitions" structure of human societies, connecting individuals in different communities and hence creating opportunities for cultural transmission among and within groups at warp speed.

\section{FAMILY AND SOCIALITY}

"Why are we all alone [in]... our tendency and ability to cooperate and compete in social groups of millions?" Alexander (1990b, p. 1)

“... our foraging ancestors evolved a novel social structure that emphasized bilateral kin associations, frequent brother-sister affiliation, important affinal alliances, and coresidence with many unrelated individuals." Hill et al. (2011, p. 1289)

Human sociality is remarkable in many respects. Our potential for flexible coalitions and alliances is exceptional (e.g., Chagnon, 1988; Choi and Bowles, 2007; cf. Fragaszy and Visalberghi, 1990; Bissonnette et al., 2015; Vale et al., 2021), and has deep evolutionary roots (Wrangham, 1999; Leblanc, 2003; Churchill et al., 2009; Feldblum et al., 2021). The origins are posited to involve unusual aspects of human family relationshipsstable breeding bonds and fathering, brother-sister bonds, grandparenting, bilateral kin bonds, affinal bonds-that facilitate interaction among individuals residing in different groups and thereby kindle cumulative culture (Alexander, 1979; Hrdy, 1981; Chapais, 2008; Flinn, 2017). These relationships are underpinned by evolved human neurobiological and neuroendocrinological mechanisms (MacDonald and MacDonald, 2010; Rilling and Mascaro, 2017; Stout and Hecht, 2017; Habecker and Flinn, 2019) but are flexible and diverse (e.g., Walker et al., 2010). Studies of social networks in hunter-gatherer bands are consistent with this family sociality link (Hill et al., 2011; Walker et al., 2011, 2013; Migliano et al., 2017, 2020), and appear to have a long prehistory (Mcbrearty and Brooks, 2000; Coward and Grove, 2011; Sikora et al., 2017; Brooks et al., 2018; Lombard and Högberg, 2021).

\section{CULTURE AND IMAGINATION}

The social world is a rich source of useful information for cognitive development. The human brain appears designed by natural selection to acquire and use information from other minds (Flinn, 1997; Bjorklund and Pellegrini, 2002; Adolphs, 2003; Sterelny, 2012). Transmission via social learning might seem to enable "culture" having its own evolutionary system with separate inheritance mechanisms (for reviews, see Dawkins, 1982; Laland et al., 2000; Henrich and McElreath, 2003; Richerson and Boyd, 2005). Other perspectives emphasize the biology of learning (e.g., Heyes and Galef, 1996; Shettleworth, 1998; Tomasello, 1999; Galef, 2004), where "culture" is viewed as an aspect of phenotypic plasticity (Flinn and Alexander, 1982; Alexander, 2006).

My intent here is to expand the evolutionary perspective of culture beyond the concepts of "dual-inheritance" or of "evoked culture" as behavioral responses to variable environments influenced by task-specific psychological modules. I suggest that evolutionary developmental biology and its reemphasis of the complexity of ontogeny (West-Eberhard, 2003) may provide important insights into culture and its creative variants (Alexander, 1990a; Heyes and Frith, 2014).

Phenotypic variation involves genetic differences and ontogenetic responses to the environment (Schlichting and Pigliucci, 1998; Gottlieb, 2002; West-Eberhard, 2003). Learning biases involve similar "reaction norms" (Heyes and Galef, 1996). Cultural variations have added complexities for inferring evolutionary design. The "creative neurons" and cumulative culture expand human behavior in extraordinary and unique ways, including the arts, literature, spiritual beliefs, technology, and complex sociality (Carroll, 2013; Muthukrishna and Henrich, 2016; Dubourg and Baumard, 2021).

Culture may be viewed as a dynamic information pool that coevolved with intelligence, including social learning aptitudes and language (Flinn, 1997; Sterelny, 2007; Pagel, 2012; Legare and Nielsen, 2015). As the power of information in hominin social interaction increased, culture and tradition were critical for social cooperation and competition (Coe, 2003; Sternberg and Grigorenko, 2004; Baumeister, 2005; Birch and Heyes, 2021). Displays of creativity, if appreciated and rewarded, can be avenues to social success.

Innovation is key. Without new ideas, cumulative culture has nowhere to go. Imagination and creativity fuel the informational arms race that underlies culture. Static reaction norms that influence evoked culture within specific domains (Tooby and Cosmides, 1992; Buss, 1995) are useful but insufficient. The human mind is not constrained to a predetermined Pleistocene set of options (Rogers, 1988). Creative culture goes beyond simple constrained phenotypic plasticity; the constraints must contend with novelties generated from collective imaginations. The human jukebox advances beyond an old selection of tunes; the Beatles displaced Elvis who borrowed from the Blues (see Wood et al., 2021). In some domains, better mousetraps keep beating last year's models.

Keeping pace in hominin red queen social competition involves imitation of success. Leading the pack requires creativity to produce new solutions to beat the current winning strategies. Informational "mutations," however, are risky; hence the increasing advantage of cognitive abilities that could refine choices among imagined innovations in dynamic, complex social scenarios (Liberman and Trope, 2008). The theater of the mind that allows humans to "understand other persons as intentional agents" (Tomasello, 1999, p. 526) is a testing ground for evaluation and refinement of creative solutions to the never-ending novelty of social arms races. Selecting the potential winners from novel information generated by the creative mind likely involves cognitive mechanisms for recursive pattern recognition in the open domains of language (Deacon, 1997; Nowak et al., 2001), social dynamics (Flinn and Ward, 2005; Geary, 2005; Shipton, 2019), and technology (Osiurak and Reynaud, 2019). The evolutionary basis for these skills underlying cumulative culture involves a process of "runaway social selection" (Flinn and Alexander, 2007). 


\section{IMAGINATION AND RUNAWAY SOCIAL SELECTION}

Darwin (1871) distinguished between (a) selection from environmental factors such as predators, climate, and food, and (b) selection from interactions among conspecifics (i.e., competition among members of the same species for resources such as nest sites, food, and mates). We may consider the former natural selection and the latter social selection-sexual selection a special subtype (West-Eberhard, 1983). Evolutionary changes resulting from these two types of selection-natural and social-are often different in significant ways (West-Eberhard, 2003; Alexander, 2006).

Natural selection resulting from interactions between species, for example with pathogen-host red queen evolution (Hamilton et al., 1990), can be intense and ongoing. A significant portion of genetic changes in human evolution occurred in response to infectious disease (Karlsson et al., 2014). Intraspecific social competition may also cause rapid evolutionary changes (Hamilton, 1970; Connell, 1983). A significant portion of genetic changes in human evolution involved changes in the brain (Preuss, 2012; Wei et al., 2019). Reduced constraints from natural selection (predators, climate, foraging, ...), in combination with increased social competition, can result in a runaway process. Human evolution evidences such conditions (Flinn et al., 2005; Alexander, 2006). Hominins increasingly became their own potent selective pressure via social competition involving coalitions (Alexander, 1990b; Wrangham, 1999; Geary and Flinn, 2001, 2002; Leblanc, 2003; Choi and Bowles, 2007; Summers et al., 2020; e.g., Chagnon, 1988; Flinn et al., 2012) and control of their ecologies via niche construction (Deacon, 1997; OdlingSmee et al., 2013). In combination with changes in population density, mobility, and opportunities for exploitation of new environments, the push for information was on.

The most exceptional human mental aptitudes-language, imagination, self-awareness, Theory of Mind (ToM), foresight, mental time travel, and consciousness-involve social relationships (Dunbar, 1997; Siegal and Varley, 2002; Tulving, 2002; Adolphs, 2003; Heyes, 2003; Geary, 2005; Suddendorf et al., 2009). Human sociality involves multiple-party reciprocity and shifting nested sub-coalitions that have high informationprocessing demands for the cognitive mechanisms that underlie social competency. Social competition within and among hominin communities had increasing amounts of novel information and creative strategies. Creative culture and social-scenario building were increasingly important selective pressures on the evolving brain. Social cleverness enhanced by the powers of imagination could subsequently catalyze aesthetics, beliefs in the supernatural, fictional storytelling, and technological innovations.

\section{EVOLUTION OF THE CREATIVE CULTURAL BRAIN}

The human brain has high metabolic costs (Kuzawa et al., 2014), takes years to develop (Leigh, 2004), evolved rapidly
(Lee and Wolpoff, 2003; Bruner, 2021), enables behavior to change quickly, and generates high levels of novel information. We have posited that its primary functions include engaging with other human brains (Alexander, 1989; Adolphs, 2003; Gallagher and Frith, 2003; Roth and Dicke, 2005; Dunbar, 2020). Success is achieved not by strength, foot-speed or antibody production but by data processing in the social mind.

Some of the least explored frontiers of creativity from the Tinbergen (1963) perspective (for review of Tinbergen's integration of questions from development, adaptive function, mechanisms, and evolutionary history, see Pfaffa et al., 2019) are the neurobiological and neuroendocrinological mechanisms that underpin our imaginations (Jung et al., 2013). It seems unlikely that there are singular "creative neurons" or even localized modules for imagination; these abilities instead result from complex systems involving interaction among many parts of the brain (Semendeferi et al., 2001; Herrmann et al., 2007; Fink et al., 2009; Dean et al., 2013; Sherwood and GómezRobles, 2017; Bruner, 2021). Some of these "social parts" of the human brain that are different from our primate relatives are asymmetrically localized in the prefrontal cortex, particularly the dorsolateral prefrontal cortex and frontal pole, but connectivity among other areas such as the hippocampus also appear relevant (Allman et al., 2001; Semendeferi et al., 2001; Rilling et al., 2002; Bzdok et al., 2016; Sherwood and Gómez-Robles, 2017; Beaty et al., 2018; Ardesch et al., 2019; Barry et al., 2019; Cabeza et al., 2020; Bruner, 2021; Parelman et al., 2021; for review, see Geary, 2005; Jung et al., 2010). These parts of the human brain enable "social scenario building" or the ability to "see ourselves as others see us so that we may cause competitive others to see us as we wish them to" (Alexander, 1990b, p. 7) and several odd cognitive abilities such as understanding sarcasm (ShamayTsoory et al., 2005), romantic love (Bartels and Zeki, 2004), and morality (Moll et al., 2005). Other mechanisms that are involved in linking family relationships to an open and creative learning environment for the human child include affiliative neuropeptides, dopamine reward circuits, and the hypothalamicanterior pituitary-adrenal system (Gimpl and Fahrenholz, 2001; Flinn, 2006; Gordon et al., 2010; MacDonald and MacDonald, 2010; Flinn et al., 2011; Habecker and Flinn, 2019, 2021; Quintana et al., 2019; Ponzi et al., 2020; Chong et al., 2021; Grinevich and Neumann, 2021).

Human life history, including the special stage of childhood, facilitates development of important social skills (Joffe, 1997; Flinn and Ward, 2005; Muehlenbein and Flinn, 2011; Sterelny, 2012; Legare, 2017), and creativity more generally. Learning, imagination, and experience are useful for developing social skills. Chronic isolation and solitude are usually unpleasant and can inhibit development of social skills and friendship networks (Bzdok and Dunbar, 2020).

\section{EVOLUTION OF THE CREATIVE CHILD}

The human infant needs a protective environment provided by intense parental and alloparental care in the context of extended kin groups and communities 
(Chisholm, 1999; Belsky, 2005; Hrdy, 2005; Flinn and Leone, 2006). The human baby is physically altricial. The infant delays investing in locomotion, defense, and food acquisition systems, instead working on mental skills such as language that produce a socially competent adult phenotype (Alexander, 1987, 1990a; Flinn, 2004). The brain grows quickly, focusing learning on the social environment (Bloom, 2000; Geary and Bjorklund, 2000; Bjorklund and Pellegrini, 2002; Geary and Huffman, 2002). The information-transmission enabled by linguistic competency provides access to the knowledge available in other human minds. Communication via language facilitates social dynamics of human communities (Dunbar, 1997; Corballis, 2017) and accelerates cumulative culture. Creativity and spread of innovations is enabled by recursion and symbolic representation in human language.

\section{PREDICTING THE PATHWAYS OF INFORMATIONAL NOVELTY}

Humans generate extraordinary levels of novelty by cognitive processing of abstract mental representations. Imaginative human minds navigate a dynamic information environment of their own creation. The method to the madness is that we produce new ideas built on the old. Human culture is cumulative. Most creations, however, are flashes in the pan, fleeting experiments that did not catch on. What accumulates is part chance, and part filtering by a multitude of minds designed by selection to make good choices.

The apparent mayhem of cultural information may result in part because it is a fundamental aspect of human social coalitions. Seemingly arbitrary shifts in cultural traits-music, art, perceptions of beauty, flags, clothing styles, recipes, dialectsmay involve information "arms races" and our special sensitivity

\section{REFERENCES}

Adolphs, R. (2003). Cognitive neuroscience of human social behavior. Nat. Rev. Neurosci. 4, 165-178.

Alexander, R. D. (1979). Darwinism And Human Affairs. Seattle: University of Washington Press.

Alexander, R. D. (1987). The Biology Of Moral Systems. Hawthorne, NY: Aldine.

Alexander, R. D. (1989). "Evolution of the human psyche," in The Human Revolution, eds P. Mellars and C. Stringer (Chicago: University of Chicago Press), 455-513.

Alexander, R. D. (1990b). How Humans Evolved: reflections On The Uniquely Unique Species. Ann Arbo: Special Publication of the University of Michigan Museum of Zoology, 1-38.

Alexander, R. D. (1990a). Epigenetic rules and Darwinian algorithms: the adaptive study of learning and development. Ethol. Sociobiol. 11, 1-63.

Alexander, R. D. (2006). The challenge of human social behavior. Evol. Psychol. 4, $1-32$.

Allman, J. M., Hakeem, A., Erwin, J. M., Nimchinsky, E., and Hof, P. (2001). The anterior cingulate cortex: the evolution of an interface between emotion and cognition. Ann. N. Y. Acad. Sci. 935, 107-117. doi: 10.1111/j.1749-6632.2001. tb03476.x

Ardesch, D. J., Scholtens, L. H., Longchuan, L., Preuss, T. M., Rilling, J. K., and Van den Heuvel, M. P. (2019). Evolutionary expansion of connectivity between to status and social context (e.g., Boyer, 1998; Carruthers, 2002; Sperber and Hirschfeld, 2004; De Dreu et al., 2010; Cabeza et al., 2020). Culture is contested because it is a contest worth winning.

Conformity and imitation of leaders and other high status models may push culture in directions contrary to predictions from simple functional concerns or evolved psychological mechanisms. Hence the apparent lack of a simple biological utilitarianism of culture and the significance of historical context and social power (Wolf, 2001). Deconstruction-analysis of meaning of the words and actions of others-is a complicated but necessary enterprise, for we are all players in the social arena trying to outmaneuver one another, but often by prosocial tactics. We are evolved participants cooperating and competing in a dynamic, creative cultural context (Kenrick et al., 2003; Sherwood and Gómez-Robles, 2017); our imaginations pushing the envelopes of phenotypic plasticity.

\section{DATA AVAILABILITY STATEMENT}

The original contributions presented in the study are included in the article/supplementary material, further inquiries can be directed to the corresponding author/s.

\section{AUTHOR CONTRIBUTIONS}

The author confirms being the sole contributor of this work and has approved it for publication.

\section{FUNDING}

This work was supported by the Baylor University, Department of Anthropology.

multimodal association areas in the human brain compared with chimpanzees. Proc. Natl. Acad. Sci. U. S. A. 116, 7101-7106. doi: 10.1073/pnas.1818512116

Bandini, E., and Harrison, R. A. (2020). Innovation in chimpanzees. Biol. Rev. 95, 1167-1197. doi: 10.1111/brv.12604

Barry, D. N., Barnes, G. R., Clark, I. A., and Maguire, E. A. (2019). The neural dynamics of novel scene imagery. J. Neurosci. 39, 4375-4386. doi: 10.1523/ jneurosci.2497-18.2019

Bartels, A., and Zeki, S. (2004). The neural correlates of maternal and romantic love. NeuroImage 21, 1155-1166. doi: 10.1016/j.neuroimage.2003.11.003

Baumeister, R. F. (2005). The Cultural Animal: human Nature, Meaning, And Social Life. Oxford: Oxford University Press.

Beaty, R. E., Kenett, Y. N., Christensen, A. P., Rosenberg, M. D., Benedek, M., Chen, Q., et al. (2018). Robust prediction of individual creative ability from brain functional connectivity. Proc. Natl. Acad. Sci. U. S. A. 115, 1087-1092. doi: $10.1073 /$ pnas. 1713532115

Belsky, J. (2005). "Differential susceptibility to rearing influence: an evolutionary hypothesis and some evidence," in Origins Of The Social Mind: evolutionary Psychology And Child Development, eds B. J. Ellis and D. F. Bjorklund (New York: Guilford), 139-163.

Birch, J., and Heyes, C. (2021). The cultural evolution of cultural evolution. Philos. Trans. R. Soc. Lond. B Biol. Sci. 376:20200051. doi: 10.1098/rstb.2020.0051

Bissonnette, A., Perry, S., Barrett, L., Mitani, J. C., Flinn, M., Gavrilets, S., et al. (2015). Coalitions in theory and reality: a review of pertinent 
variables and processes. Behaviour 152, 1-56. doi: 10.1163/1568539X0000 3241

Bjorklund, D. F., and Pellegrini, A. D. (2002). The Origins Of Human Nature: evolutionary Developmental Psychology. Washington, DC: American Psychological Association.

Bloom, P. (2000). How Children Learn The Meanings Of Words. Cambridge, MA: MIT Press.

Boyer, P. (1998). Cognitive tracks of cultural inheritance: how evolved intuitive ontology governs cultural transmission. Am. Anthropol. 100, 876-889. doi: 10.1525/aa.1998.100.4.876

Brooks, A. S., Yellen, J. E., Potts, R., Behrensmeyer, A. K., Deino, A. L., Leslie, D. E., et al. (2018). Long-distance stone transport and pigment use in the earliest Middle Stone Age. Science 360, 90-94. doi: 10.1126/science.aao2646

Brosnan, S. F., and Hopper, L. M. (2014). Psychological limits on animal innovation. Anim. Behav. 92, 325-332. doi: 10.1016/j.anbehav.2014.02.026

Bruner, E. (2021). Evolving human brains: paleoneurology and the fate of middle pleistocene. J. Archaeol. Method Theory 28, 76-94. doi: 10.1007/s10816-02009500-8

Buss, D. M. (1995). Evolutionary psychology: a new paradigm for psychological science. Psychol. Inq. 6, 1-30. doi: 10.1207/s15327965pli0601_1

Bzdok, D., and Dunbar, R. I. M. (2020). The neurobiology of social distance. Trends Cogn. Sci. 24, 717-733. doi: 10.1016/j.tics.2020.05.016

Bzdok, D., Hartwigsen, G., Reid, A., Laird, A. R., Fox, P. T., and Eickhoff, S. B. (2016). Left inferior parietal lobe engagement in social cognition and language. Neurosci. Biobehav. Rev. 68, 319-334. doi: 10.1016/j.neubiorev.2016.02.024

Cabeza, R., Becker, M., and Davis, S. W. (2020). Are the hippocampus and its network necessary for creativity? Proc. Natl. Acad. Sci. U. S. A. 117, 1387013872. doi: 10.1073/pnas.2008601117

Campbell, D. T. (1960). Blind variation and selective retention in creative thought as in other knowledge processes. Psychol. Rev. 67, 380-400. doi: 10.1037/ h0040373

Carroll, J. (2013). A rationale for evolutionary studies of literature. Sci. Study Lit. 3, 8-15. doi: 10.1075/ssol.3.1.03car

Carruthers, P. (2002). "The evolution of consciousness," in Evolution and the human mind: modularity, language and meta-cognition, eds P. Carruthers and A. Chamberlain (Cambridge, England: Cambridge University Press), 254-276.

Chagnon, N. A. (1988). Life histories, blood revenge, and warfare in a tribal population. Science 239, 985-992. doi: 10.1126/science.239.4843.985

Chagnon, N. A., Lynch, R. F., Shenk, M. S., Hames, R., and Flinn, M. V. (2017). Cross cousin marriage among the Yanomamö shows evidence of parentoffspring conflict and mate competition between siblings. Proc. Natl. Acad. Sci. U. S. A. 114, E2590-E2607. doi: 10.1073/pnas.1618655114

Chapais, B. (2008). Primeval Kinship: how Pair-Bonding Gave Birth To Human Society. Cambridge (MA): Harvard University Press.

Chisholm, J. (1999). Death, Hope, And Sex. Cambridge, England: Cambridge University Press.

Choi, J.-K., and Bowles, S. (2007). The coevolution of parochial altruism and war. Science 318, 636-640. doi: 10.1126/science.1144237

Chong, A., Tolomeo, S., Xiong, Y., Angeles, D., Cheung, M., Becker, B., et al. (2021). Blending oxytocin and dopamine with everyday creativity. Nat. Sci. Rep. 11:16185.

Churchill, S. E., Franciscus, R., McKean-Peraza, H. A., Daniel, J., and Warren, B. R. (2009). Shanidar 3 Neandertal rib puncture wound and paleolithic weaponry. J. Hum. Evol. 57, 163-178. doi: 10.1016/j.jhevol.2009.05.010

Coe, K. (2003). The ancestress hypothesis: visual art as adaptation. New Brunswick, NJ: Rutgers University Press.

Connell, J. (1983). On the prevalence and relative importance of interspecific competition: evidence from field experiments. Am. Nat. 122, 661-696. doi: $10.1086 / 284165$

Corballis, M. C. (2017). The Truth About Language, What It Is And Where It Came From. Chicago and London: University of Chicago Press.

Coward, F., and Grove, M. (2011). Beyond the tools: social innovation and hominin evolution. Paleoanthropology 2011, 111-129. doi: 10.4207/PA.2011.ART46

Darwin, C. R. (1871). The Descent Of Man, And Selection In Relation To Sex. London: John Murray, 1.

Dawkins, R. (1982). The Extended Phenotype. Oxford: Oxford University Press.

De Dreu, C., Greer, L., Handgraaf, M., Shalvi, S., Van Kleef, G., Baas, M., et al. (2010). The neuropeptide oxytocin regulates parochial altruism in intergroup conflict among humans. Science 328, 1408-1411. doi: 10.1126/science.1189047
Deacon, T. W. (1997). The Symbolic Species: the Co-Evolution Of Language And The Brain. New York: Norton.

Dean, L. G., Kendal, R. L., Schapiro, S. J., Thierry, B., and Laland, K. N. (2013). Identification of the social and cognitive processes underlying human cumulative culture. Science 335, 1114-1118. doi: 10.1126/science.1213969

Dubourg, E., and Baumard, N. (2021). Why imaginary worlds? The psychological foundations and cultural evolution of fictions with imaginary worlds. Behav. Brain Sci. 1-52. doi: 10.1017/S0140525X21000923

Duda, P., and Zrzavý, J. (2013). Evolution of life history and behavior in Hominidae: towards phylogenetic reconstruction of the chimpanzee-human last common ancestor. J. Hum. Evol. 65, 424-446. doi: 10.1016/j.jhevol.2013. 07.009

Dunbar, R. I. M. (1997). Grooming, Gossip And The Evolution Of Language. Cambridge, MA: Harvard University Press.

Dunbar, R. I. M. (2020). Structure and function in human and primate social networks: implications for diffusion, network stability and health. Proc. R. Soc. A Math. Phys. Eng. Sci. 476:20200446. doi: 10.1098/rspa.2020.0446

Feldblum, J. T., Krupenye, C., Bray, J., Pusey, A. E., and Gilby, I. C. (2021). Social bonds provide multiple pathways to reproductive success in wild male chimpanzees. iScience 24:102864. doi: 10.1016/j.isci.2021.102864

Fink, A., Grabner, R. H., Benedek, M., Reishofer, G., Hauswirth, V., Fally, M., et al. (2009). The creative brain: investigation of brain activity during creative problem solving by means of EEG and fMRI. Hum. Brain Mapp. 30, 734-748. doi: 10.1002/hbm.20538

Flinn, M. V. (1997). Culture and the evolution of social learning. Evol. Hum. Behav. 18, 23-67. doi: 10.1016/s1090-5138(96)00046-3

Flinn, M. V. (2004). "Culture and developmental plasticity: evolution of the social brain," in Evolutionary Perspectives On Child Development, eds K. MacDonald and R. L. Burgess (Thousand Oaks, CA: Sage), 73-98. doi: 10.4135/ 9781452233574.n3

Flinn, M. V. (2006). Evolution and ontogeny of stress response to social challenge in the human child. Dev. Rev. 26, 138-174. doi: 10.1186/s12868-016-0 283-6

Flinn, M. V. (2017). "The human family: evolutionary origins and adaptive significance," in On Human Nature, Chap. 16, eds M. Teyberanc and F. Ayala (New York: Elsevier), 251-262. doi: 10.1016/B978-0-12-420190-3.00016-8

Flinn, M. V., and Alexander, R. D. (1982). Culture theory: the developing synthesis from biology. Hum. Ecol. 10, 383-400. doi: 10.1007/bf01531192

Flinn, M. V., and Alexander, R. D. (2007). "Runaway social selection," in The Evolution of Mind, eds S. W. Gangestad and J. A. Simpson (New York: Guilford).

Flinn, M. V., Geary, D. C., and Ward, C. V. (2005). Ecological dominance, social competition, and coalitionary arms races: why humans evolved extraordinary intelligence. Evol. Hum. Behav. 26, 10-46. doi: 10.1016/j.evolhumbehav.2004. 08.005

Flinn, M. V., and Leone, D. V. (2006). Early trauma and the ontogeny of glucocorticoid stress response: grandmother as a secure base. J. Dev. Process. $1,31-68$.

Flinn, M. V., Nepomnaschy, P., Muehlenbein, M. P., and Ponzi, D. (2011). Evolutionary functions of early social modulation of hypothalamic-pituitaryadrenal axis development in humans. Neurosci. Biobehav. Rev. 35, 1611-1629. doi: 10.1016/j.neubiorev.2011.01.005

Flinn, M. V., Ponzi, D., and Muehlenbein, M. P. (2012). Hormonal mechanisms for regulation of aggression in human coalitions. Hum. Nat. 22, 68-88. doi: 10.1007/s12110-012-9135-y

Flinn, M. V., and Ward, C. V. (2005). "Evolution of the social child," in Origins of the social mind: evolutionary psychology and child development, eds B. Ellis and D. Bjorklund (London: Guilford), 19-44.

Fragaszy, D. M., and Visalberghi, E. (1990). Social processes affecting the appearance of innovative behaviours in capuchin monkeys. Folia Primatol. 54, 155-165. doi: 10.1159/000156439

Fuentes, A. (2017). The Creative Spark: how Imagination Made Humans Exceptional. New York: Penguin.

Galef, B. G. Jr. (2004). Approaches to the study of traditional behaviors of freeliving animals. Learn. Behav. 32, 53-61. doi: 10.3758/bf03196006

Gallagher, H. L., and Frith, C. D. (2003). Functional imaging of 'theory of mind'. Trends Cogn. Sci. 7, 77-83. doi: 10.1016/s1364-6613(02)00025-6

Geary, D. C. (2005). The Origin Of Mind: evolution Of Brain, Cognition, And General Intelligence. Washington, DC: American Psychological Association. 
Geary, D. C., and Bjorklund, D. F. (2000). Evolutionary developmental psychology. Child Dev. 71, 57-65.

Geary, D. C., and Flinn, M. V. (2001). Evolution of human parental behavior and the human family. Parent. Sci. Pract. 1, 5-61. doi: 10.1207/s15327922par011\% 2622

Geary, D. C., and Flinn, M. V. (2002). Sex differences in behavioral and hormonal response to social threat. Psychol. Rev. 109, 745-750. doi: 10.1037/0033-295x. 109.4.745

Geary, D. C., and Huffman, K. J. (2002). Brain and cognitive evolution: forms of modularity and functions of mind. Psychol. Bull. 128, 667-698. doi: 10.1037/ 0033-2909.128.5.667

Gimpl, G., and Fahrenholz, F. (2001). The oxytocin receptor system: structure, function, and regulation. Physiol. Rev. 81, 629-683. doi: 10.1152/physrev.2001. 81.2.629

Gordon, I., Zagoory-Sharon, O., Leckman, J. F., and Feldman, R. (2010). Oxytocin and the development of parenting in humans. Biol. Psychiatry 68, 377-382. doi: 10.1016/j.biopsych.2010.02.005

Gottlieb, G. (2002). Developmental-behavioral initiation of evolutionary change. Psychol. Rev. 109, 211-218. doi: 10.1037/0033-295x.109.2.211

Grinevich, V., and Neumann, I. D. (2021). Brain oxytocin: how puzzle stones from animal studies translate into psychiatry. Mol. Psychiatry 26, 265-279. doi: $10.1038 / \mathrm{s} 41380-020-0802-9$

Habecker, H., and Flinn, M. V. (2019). "Evolution of hormonal mechanisms for human sociality," in Handbook of Cognitive Archaeology: psychology in PreHistory, eds T. Henley, M. Rossano, and E. Kardas (Milton Park UK: Routledge Press), 58-85. doi: 10.4324/9780429488818-4

Habecker, H., and Flinn, M. V. (2021). "Neuroendocrinological mechanisms for human emotions," in Oxford Handbook of Evolutionary Psychology and Emotions, eds L. Al-Shawaf and T. Shackelford (Oxford UK: OUP).

Hamilton, W. (1970). Selfish and spiteful behaviour in an evolutionary model. Nature 228, 1218-1220. doi: 10.1038/2281218a

Hamilton, W. D., Axelrod, R., and Tanese, R. (1990). Sexual reproduction as an adaptation to resist parasites. Proc. Natl. Acad. Sci. U. S. A. 87, 3566-3573. doi: 10.1073/pnas.87.9.3566

Hawkes, K. (2020). Cognitive consequences of our grandmothering life history: cultural learning begins in infancy. Philos. Trans. R. Soc. Lond. B Biol. Sci. 375:2019051. doi: 10.1098/rstb.2019.0501

Henrich, J., and McElreath, R. (2003). The evolution of cultural evolution. Evol. Anthropol. 12, 123-135.

Herrmann, E., Call, J., Hernàndez-Lloreda, M. V., Hare, B., and Tomasello, M. (2007). Humans have evolved specialized skills of social cognition: the cultural intelligence hypothesis. Science 317, 1360-1366. doi: 10.1126/science.114 6282

Heyes, C. (2003). Four routes of cognitive evolution. Psychol. Rev. 110, 713-727. doi: $10.1037 / 0033-295 x \cdot 110.4 .713$

Heyes, C. M., and Frith, C. D. (2014). The cultural evolution of mind reading. Science 344:1243091. doi: 10.1126/science

Heyes, C. M., and Galef, B. G. Jr. (eds) (1996). Social Learning In Animals: the Roots Of Culture. Cambridge, Massachusetts: Academic Press.

Hill, K. R., Walker, R. S., Božičević, M., Eder, J., Headland, T., Hewlett, B., et al. (2011). Co-residence patterns in hunter-gatherer societies show unique human social structure. Science 331, 1286-1289. doi: 10.1126/science.119 9071

Hrdy, S. B. (1981). The Woman that Never Evolved. Cambridge: Harvard University Press.

Hrdy, S. B. (2005). "Evolutionary context of human development: the cooperative breeding model," in Attachment and bonding: a new synthesis, eds C. S. Carter and L. Ahnert (Cambridge, MA: MIT Press).

Hrdy, S. B. (2009). Mothers and Others: the Evolutionary Origins of Mutual Understanding. Cambridge: Harvard University Press.

Joffe, T. H. (1997). Social pressures have selected for an extended juvenile period in primates. J. Hum. Evol. 32, 593-605. doi: 10.1006/jhev.1997. 0140

Jung, R. E., Mead, B. S., Carrasco, J., and Flores, R. A. (2013). The structure of creative cognition in the human brain. Front. Hum. Neurosci. 7:330. doi: 10.3389/fnhum.2013.00330

Jung, R. E., Segall, J. M., Bockholt, H. J., Flores, R. A., Smith, S. M., Chavez, R. S., et al. (2010). Neuroanatomy of creativity. Hum. Brain Mapp. 31, 398-409.
Karlsson, E., Kwiatkowski, D., and Sabeti, P. (2014). Natural selection and infectious disease in human populations. Nat. Rev. Genet. 15, 379-393. doi: $10.1038 / \operatorname{nrg} 3734$

Kenrick, D. T., Li, N., and Butner, J. (2003). Dynamical evolutionary psychology: individual decision-rules and emergent social norms. Psychol. Rev. 1, 3-28. doi: 10.1037/0033-295x.110.1.3

Kuzawa, C. W., Chugani, H. T., Grossman, L. I., Lipovich, L., Muzik, O., Hof, P. R., et al. (2014). Metabolic costs and evolutionary implications of human brain development. Proc. Natl. Acad. Sci. U. S. A. 11, 13010-13015. doi: 10.1073/ pnas. 1323099111

Laland, K. N., Odling-Smee, J., and Feldman, M. W. (2000). Niche construction, biological evolution, and cultural change. Behav. Brain Sci. 23, 131-175. doi: $10.1017 / \mathrm{s} 0140525 \times 00002417$

Leblanc, S. A. (2003). Constant Battles: the Myth Of The Peaceful, Noble Savage. New York: St. Martin's Press.

Lee, S. H., and Wolpoff, M. H. (2003). The pattern of evolution in Pleistocene human brain size. Paleobiology 29, 186-196. doi: 10.1666/0094-8373(2003) $029<0186$ :tpoeip $>2.0$. co; 2

Lefebvre, L., Reader, S. M., and Sol, D. (2004). Brains, innovations and evolution in birds and primates. Brain Behav. Evol. 63, 233-246. doi: 10.1159/000076784

Legare, C. H. (2017). Cumulative cultural learning: development and diversity. Proc. Natl. Acad. Sci. U. S. A. 114, 7877-7883. doi: 10.1073/pnas.1620743114

Legare, C. H., and Nielsen, M. (2015). Imitation and innovation: the dual engines of cultural learning. Trends Cogn. Sci. 19, 688-699. doi: 10.1016/j.tics.2015.08.005

Leigh, S. R. (2004). Brain growth, cognition, and life history in primate and human evolution. Am. J. Primatol. 62, 139-164. doi: 10.1002/ajp.20012

Liberman, N., and Trope, Y. (2008). The psychology of transcending the here and now. Science 322, 1201-1205. doi: 10.1126/science.1161958

Lombard, M., and Högberg, A. (2021). Four-field co-evolutionary model for human cognition: variation in the Middle Stone Age/Middle Palaeolithic. J. Archaeol. Method Theory 28, 142-177. doi: 10.1007/s10816-020-09502-6

MacDonald, K., and MacDonald, T. M. (2010). The peptide that binds: a systematic review of oxytocin and its prosocial effects in humans. Harv. Rev. Psychiatry 18, 1-21. doi: $10.3109 / 10673220903523615$

Macfarlan, S. J., Walker, R. S., Flinn, M. V., and Chagnon, N. A. (2014). Lethal coalitionary aggression and long-term alliances among Yanomamö men. Proc. Natl. Acad. Sci. U. S. A. 111, 16662-16669. doi: 10.1073/pnas.1418639111

Mcbrearty, S., and Brooks, A. S. (2000). The revolution that wasn't: a new interpretation of the origin of modern human behavior. J. Hum. Evol. 39, 453-563. doi: 10.1006/jhev.2000.0435

Migliano, A. B., Battiston, F., Viguier, S., Page, A. E., Dyble, M., Schlaepfer, R., et al. (2020). Hunter-gatherer multilevel sociality accelerates cumulative cultural evolution. Sci. Adv. 6:eaax5913. doi: 10.1126/sciadv.aax5913

Migliano, A. B., Page, A. E., Gómez-Gardeñes, J., Salali, G. D., Viguier, S., Dyble, M., et al. (2017). Characterization of hunter-gatherer networks and implications for cumulative culture. Nat. Hum. Behav. 1:0043.

Milks, A., Parker, D., and Pope, M. (2019). External ballistics of Pleistocene handthrown spears: experimental performance data and implications for human evolution. Sci. Rep. 9:820. doi: 10.1038/s41598-018-37904-w

Moll, J., Zahn, R., de Oliveira-Souza, R., Krueger, F., and Grafman, J. (2005). The neural basis of human moral cognition. Nat. Rev. Neurosci. 6, 799-809. doi: $10.1038 / \mathrm{nrn} 1768$

Muehlenbein, M., and Flinn, M. V. (2011). "Pattern and process of human life history evolution," in Oxford handbook of life history, Chap. 23, eds T. Flatt and A. Heyland (Oxford: Oxford University Press), 153-168. doi: 10.1093/acprof: oso/9780199568765.003.0012

Muthukrishna, M., and Henrich, J. (2016). Innovation in the collective brain. Philos. Trans. R. Soc. B 371:20150192. doi: 10.1098/rstb.2015.0192

Nowak, M. A., Komarova, N. L., and Niyogi, P. (2001). Evolution of universal grammar. Science 291, 114-118.

Odling-Smee, F. J., Laland, K. N., and Feldman, M. W. (2013). Niche Construction: the Neglected Process in Evolution (MPB-37). Princeton: Princeton University Press.

Osiurak, F., and Reynaud, E. (2019). The elephant in the room: what matters cognitively in cumulative technological culture. Behav. Brain Sci. 43:e156. doi: 10.1017/S0140525X19003236

Pagel, M. D. (2012). Wired for Culture: origins of the Human Social Mind. New York: W.W. Norton. 
Parelman, J. M., Doré, B. P., Cooper, N., O’Donnell, M. B., Chan, H.-Y., and Falk, E. B. (2021). Overlapping functional representations of self- and other-related thought are separable through multivoxel pattern classification. Cereb. Cortex [Epub Online ahead of print]. doi: 10.1093/cercor/bhab272

Pfaffa, D., Tabanskya, I., and Haubensak, W. (2019). Tinbergen's challenge for the neuroscience of behavior. Proc. Natl. Acad. Sci. U. S. A. 116, 9704-9710.

Ponzi, D., Flinn, M. V., Muehlenbein, M. P., and Nepomnaschy, P. (2020). Hormones and human developmental plasticity. Mol. Cell. Endocrinol. 505:110721. doi: 10.1016/j.mce.2020.110721

Preuss, T. M. (2012). Human brain evolution: from gene discovery to phenotype discovery. Proc. Natl. Acad. Sci. U. S. A. 109, 10709-10716. doi: 10.1073/pnas. 1201894109

Quintana, D. S., Rokicki, J., van der Meer, D., Alnæs, D., Kaufmann, T., CórdovaPalomera, A., et al. (2019). Oxytocin pathway gene networks in the human brain. Nat. Commun. 10:668.

Richerson, P. J., and Boyd, R. (2005). Not By Genes Alone: how Culture Transformed Human Evolution. Chicago: University of Chicago Press.

Rilling, J., Gutman, D., Zeh, T., Pagnoni, G., Berns, G., and Kilts, C. (2002). A neural basis for social cooperation. Neuron 35, 395-405. doi: 10.1016/s0896-6273(02) 00755-9

Rilling, J. K., and Mascaro, J. S. (2017). The neurobiology of fatherhood. Curr. Opin. Psychol. 15, 26-32. doi: 10.1016/j.copsyc.2017.02.013

Rogers, A. R. (1988). Does biology constrain culture? Am. Anthropol. 90, 819-831. doi: 10.1525/aa.1988.90.4.02a00030

Roth, G., and Dicke, U. (2005). Evolution of the brain and intelligence. Trends Cogn. Sci. 9, 250-257.

Schlichting, C. D., and Pigliucci, M. (1998). Phenotypic evolution: a reaction norm perspective. Sunderland, MA: Sinauer Associates.

Semendeferi, K., Armstrong, E., Schleicher, A., Zilles, K., and van Hoesen, G. W. (2001). Prefrontal cortex in humans and apes: a comparative study of area 10. Am. J. Phys. Anthropol. 114, 224-241. doi: 10.1002/1096-8644(200103)114: $3<224$ ::aid-ajpa1022>3.0.co;2-i

Shamay-Tsoory, S. G., Tomer, R., and Aharon-Peretz, J. (2005). The neuroanatomical basis of understanding sarcasm and its relationship to social cognition. Neuropsychology 19, 288-300. doi: 10.1037/0894-4105.19.3.288

Sherwood, C. C., and Gómez-Robles, A. (2017). Brain plasticity and human evolution. Annu. Rev. Anthropol. 46, 399-419. doi: 10.1146/annurev-anthro102215-100009

Shettleworth, S. J. (1998). Cognition, Evolution, And Behavior. New York: Oxford University Press.

Shipton, C. (2019). "Three stages in the evolution of human cognition: normativity, recursion, and abstraction," in Handbook of Cognitive Archaeology: psychology in Pre-History, eds T. Henley, M. Rossano, and E. Kardas (Milton Park UK: Routledge Press), 153-173. doi: 10.4324/9780429488818-9

Siegal, M., and Varley, R. (2002). Neural systems involved with “Theory of Mind.”. Nat. Rev. Neurosci. 3, 463-471. doi: 10.1038/nrn844

Sikora, M., Seguin-Orlando, A., Sousa, V. C., Albrechtsen, A., Korneliussen, T., Ko, A., et al. (2017). Ancient genomes show social and reproductive behavior of early Upper Paleolithic foragers. Science 358, 659-662. doi: 10.1126/science. aao 1807

Sperber, D., and Hirschfeld, L. (2004). The cognitive foundations of cultural stability and diversity. Trends Cogn. Sci. 8, 40-46. doi: 10.1016/j.tics.2003.11. 002

Sterelny, K. (2007). Social intelligence, human intelligence and niche construction. Philos. Trans. R. Soc. Lond. B Biol. Sci. 362, 719-730. doi: 10.1098/rstb.2006

Sterelny, K. (2012). The Evolved Apprentice: how Evolution Made Humans Unique. Cambridge, Massachusetts: MIT Press.

Sternberg, R. J., and Grigorenko, E. L. (2004). Intelligence and culture: how culture shapes what intelligence means, and the implications for a science of well-being. Philos. Trans. R. Soc. Lond. Ser. B 359, 1427-1434. doi: 10.1098/rstb.2004.1514

Stout, D., and Hecht, E. E. (2017). Evolutionary neuroscience of cumulative culture. Proc. Natl. Acad. Sci. U. S. A. 114, 7861-7868. doi: 10.1073/pnas.1620738114

Suddendorf, T., Addis, D. R., and Corballis, M. C. (2009). Mental time travel and the shaping of the human mind. Philos. Trans. R. Soc. Lond. Biol. Sci. 364, 1317-1324. doi: 10.1098/rstb.2008.0301

Summers, K., Crespi, B., and Flinn, M. V. (2020). Were humans their own most important selective pressure for cooperation and morality? Evol. Behav. Sci. 14, 238-251. doi: 10.1037/ebs0000203
Tinbergen, N. (1963). On aims and methods of ethology. Z. Tierpsychol. 20, 410-433. doi: 10.1111/j.1439-0310.1963.tb0 1161.x

Tomasello, M. (1999). The Cultural Origins Of Human Cognition. Cambridge, MA: Harvard University Press.

Tomasello, M. (2016). The ontogeny of cultural learning. Curr. Opin. Psychol. 8, 1-4. doi: 10.1016/j.copsyc.2015.09.008

Tooby, J., and Cosmides, L. (1992). "The psychological foundations of culture," in The Adapted Mind, eds J. H. Barkow, L. Cosmides, and J. Tooby (Oxford, England: Oxford University Press), 19-136.

Tulving, E. (2002). Episodic memory: from mind to brain. Annu. Rev. Psychol. 53, 1-25. doi: 10.1146/annurev.psych.53.100901.13 5114

Vale, G. L., McGuigan, N., Burdett, E., Lambeth, S. P., Lucas, A., Rawlings, B., et al. (2021). Why do chimpanzees have diverse behavioral repertoires yet lack more complex cultures? Invention and social information use in a cumulative task. Evol. Hum. Behav. 42, 247-258. doi: 10.1016/j.evolhumbehav.2020.1 1.003

Wadley, L. (2021). What stimulated rapid, cumulative innovation after 100,000 years ago? J. Archaeol. Method Theory 28, 120-141. doi: 10.1007/s10816-02009499-y

Walker, R. S., Beckerman, S., Flinn, M. V., Gurven, M., von Reuden, C. R., Kramer, K. L., et al. (2013). Living with kin in lowland horticultural societies. Curr. Anthropol. 54, 96-103. doi: 10.1086/668867

Walker, R. S., Flinn, M. V., and Hill, K. (2010). The evolutionary history of partible paternity in lowland South America. Proc. Natl. Acad. Sci. U. S. A. 107, 19195-19200. doi: 10.1073/pnas.100259 8107

Walker, R. S., Hill, K., Flinn, M. V., and Ellsworth, R. (2011). Evolutionary history of hunter-gatherer marriage practices. PLoS One 6:e19066. doi: 10.1371/journal.pone.0019066

Wei, Y., de Lange, S. C., Scholtens, L. H., Watanabe, K., Jan Ardesch, D., Jansen, P. R., et al. (2019). Genetic mapping and evolutionary analysis of humanexpanded cognitive networks. Nat. Commun. 10:4839. doi: 10.1038/s41467019-12764-8

West-Eberhard, M. J. (1983). Sexual selection, social competition, and speciation. Q. Rev. Biol. 58, 155-183. doi: 10.1086/41 3215

West-Eberhard, M. J. (2003). Developmental Plasticity And Evolution. Oxford, England: Oxford University Press.

Whiten, A., and Erdal, D. (2012). The human socio-cognitive niche and its evolutionary origins. Philos. Trans. R. Soc. Lond. B Biol. Sci. 367, 2119-2129. doi: 10.1098/rstb.2012.0114

Wolf, E. R. (2001). Pathways Of Power: building An Anthropology Of The Modern World. Berkeley: University of California Press.

Wood, A. C. L., Kirby, K. R., Ember, C. R., Silbert, S., Passmore, S., Daikoku, H., et al. (2021). The Global Jukebox: a public database of performing arts and culture. PsyArXivpreprint doi: 10.31234/osf.io/4z9

Wrangham, R. W. (1999). Evolution of coalitionary killing. Yearb. Phys. Anthropol. 42, 1-30. doi: 10.1002/(sici)1096-8644(1999)110:29\%2B<1::aid-ajpa2>3.0. co;2-e

Conflict of Interest: The author declares that the research was conducted in the absence of any commercial or financial relationships that could be construed as a potential conflict of interest.

Publisher's Note: All claims expressed in this article are solely those of the authors and do not necessarily represent those of their affiliated organizations, or those of the publisher, the editors and the reviewers. Any product that may be evaluated in this article, or claim that may be made by its manufacturer, is not guaranteed or endorsed by the publisher.

Copyright (c) 2021 Flinn. This is an open-access article distributed under the terms of the Creative Commons Attribution License (CC BY). The use, distribution or reproduction in other forums is permitted, provided the original author(s) and the copyright owner(s) are credited and that the original publication in this journal is cited, in accordance with accepted academic practice. No use, distribution or reproduction is permitted which does not comply with these terms. 